\title{
THE EFFECT OF ZINC DIET ON DISTRIBUTION OF FATTY ACID IN BLOOD PLASMA CHYLOMICRONS
}

\author{
Aleksandra Cerovićn ${ }^{,}$Ivanka Miletić ${ }^{1}$, Duško Blagojević ${ }^{2}$, Slađana Šobajić1, \\ Miodrag Colić3, Milijana Vasiljeuska ${ }^{3}$, Milica Poznanić ${ }^{4}$ \\ 1 Faculty of Pharmacy, Department of Bromatology, Belgrade, Serbia and Montenegro \\ 2 Institute for Biological Research, Department of Physiology, Belgrade, Serbia and Montenegro \\ 3 Military Medical Academy, Department of Medical Research, Belgrade, Serbia and Montenegro \\ ${ }^{4}$ Center for Food Analysis, Department of Instrumental Chemistry, Belgrade, Serbia and Montenegro
}

Summary: The effect of dietary zinc on the distribution of fatty acids in blood plasma chylomicrons was studied. The experiment was performed on male Mongolian Gerbils, fed ad libitum for 3 weeks with standard diet, containing 8 or $38 \mathrm{mg}$ of Zn per $\mathrm{kg}$ of food (low zinc diet group, LZ, and saturated zinc diet group, SZ, respectivelly). At the 21th day gerbils were given sunflower oil by gavage. After 2.5 hours, blood was collected from abdominal vein, and samples were pooled (five animals per one sample). Chylomicron fractions were isolated by ultracentrifugation and mass of dried chylomicrons was measured. Fatty acid composition was analyzed by gas-liquid chromatography. Significantly higher amount of chylomicrons in blood plasma of SZ than in LZ group was found. In chylomicrons, following fatty acids were found: 16:0, 16:1, 17:0, 17:1, 18:0, 18:1, $18: 2,18: 3,20: 0,21: 0$ and 20:4. The amount of individual fatty acids in chylomicrons in both groups was similar, except 20:4 where lower amount in SZ group was found. Zinc diet did not affect fatty acid distribution in chylomicrons of both groups. Animals fed with zinc saturated diet had higher amount of fatty acids in blood plasma. Observed results suggest that dietary zinc influences the quantity of fatty acids absorption but not its distribution in chylomicrons.

Key words: low zinc diet, saturated zinc diet, fatty acids, chylomicrons

\section{Introduction}

Zinc, an essential trace element in eukaryotes (1), plays a structural role in a wide range of important proteins, as the component of zinc finger motif (2). Due to unadequate intakes of zinc, appeared clinical features in rats include growth retardation, dermal lesions, immunodeficiency, alopecia, male and female infertility and increased capillary permeability (3).

The results of animal studies consistently showed association between Zn-deficient diet with lipid absorption (4-6). Earlier studies investigated zinc effect on chylomicrons formation (7), composition of erytrocytes membranes, essential fatty acids metabolism (8), activity of fatty acid synthase (9) and lipoprotein lipase (10), but not fatty acids composition in chylomicrons.

\footnotetext{
Address for correspondence:

Aleksandra Cerović

Faculty of Pharmacy, Department of Bromatology

Vojvode Stepe 450, Belgrade

e-mail: cekina@yahoo.com
}

Dietary fats (triacylglycerols, sterols, phospholipids) enter the gastrointestinal tract, and digestion begins. Digestive enzymes involved in the breakdown of dietary lipids are esterases that cleave the ester bonds within triacylglycerols (lipase), phospholipids (phospholipases), and cholesteryl esters (cholesterol esterase). Most dietary triacylglycerol digestion is completed in the lumen of the small intestine, resulting in a complex mixture of diacylglycerols, monoacylglycerols and free fatty acids. Esterified cholesterol, mean-while, undergoes hydrolysis to free cholesterol and a fatty acid, catalyzed by the enzyme cholesterol esterase. The C-2 fatty acid of the phospholipid is hydrolytically removed by a specific esterase called phospholipase $\mathrm{A}_{2}$, produsing lysophospholipid and still another free fatty acid (11).

The products of the partial digestion of lipids, primarly monoacylglycerols, lysophospholipids, cholesterol and fatty acids, combine with bile salts, forming negatively charged polymolecular aggregates called micelles. 
These lipid products then pass by monomolecular diffusion into the mucosal cells (enterocyte) of the small intestine. In the mucosa cell, monoacylglycerols and fatty acids are recombined into triacylglycerols. The triacylglycerols are incorporated into lipoproteins called chylomicrons (12). Chylomicrons consist of $2.1 \%$ free cholesterol, $3.9 \%$ esterified cholesterol, $4.3 \%$ phospholipids (PL), $87 \%$ triacylglicerol and $2 \%$ proteins (13). Chylomicron PL is mostly phosphatidilcholin (PC) and is derived largely from biliary PL secreted into the intestinal lumen (14). Intestinal absorption of lipids is impaired in zinc deficiency. The impaired absorption appeared not to be due to defects in the luminal digestion of lipids, or in the mucosal uptake of hydrolytic products, but primarily to the defective intestinal formation of chylomicrons (7). Enterocyte of Zn-deficient animals accumulates lipid droplets in the enterocyte and fails to transport the lipids via chylomicrons (15). These lipid droplets exhibited a strong tendency to coalesce within the cytoplasm of the enterocyte, which suggests of altered composition of chylomicron coats caused by lack of surface components such as phospholipid (PL) and apoB $(16,17)$.

It is well known that the structure and distribution of incorporated fatty acids in chylomicrons are related to the kind of lipids ingested (18). In addition, diets with high concentrations of polyunsaturated fatty acids lead to bigger chylomicrons than do diets with low levels of polyunsaturated fatty acids, which can then be degraded more rapidly $(19,20)$.

Studies on zinc-deficient rats showed different activity of lipoprotein lipase in animals fed diets with oil which contained predominately saturated fatty acids in comparison to the oil rich with unsaturated fatty acids, but the activity of lipoprotein lipase did not differ between zinc-adequate rats fed on the same way (10).

The aim of this study was to explore influence of dietary zinc on the distribution of fatty acids in chylomicrons.

\section{Materials and Methods}

\section{Animals}

Thirty male mongolian gerbils, weight $55-60 \mathrm{~g}$, 9-10 weeks old, were used in this study. They were housed in cages, 5 animals per cage, and held under controlled conditions of illumination (light on $7 \mathrm{am}-7$ $\mathrm{pm})$ and temperature $\left(25 \pm 3^{\circ} \mathrm{C}\right)$.

\section{Meal feeding and dietary treatment}

Gerbils were assigned randomly to the following two groups: group fed with basal diet low in zinc (LZ) and group (SZ) fed with the same basal diet, but supplemented with zinc sulfate.

Recommended requirement for mongolian gerbile for $\mathrm{Zn}$ is $25 \mathrm{mg} / \mathrm{kg}$ (21). Both groups were fed for 3 weeks. LZ group was given deionized water, while SZ group was given a tap water. The access to diet and water was ad libitum.

The composition of the basal diet is given in Table I. It was prepared as described by Noh and Koo (15), with the following modification: amounts of vitamins and minerals were justified, according to the recommendations for mongolian gerbile (Table I) (21). This basal diet contained $8 \mathrm{mg}$ of $\mathrm{Zn} / \mathrm{kg}$ (LZ-diet) and was supplemented with zinc sulfate to prepare the SZ diet, $38 \mathrm{mg}$ of $\mathrm{Zn} / \mathrm{kg}$.

After 20 days, diet was taken away from all gerbils, at $1 \mathrm{pm}$ while water was avaible for consumption all the time. On following day gerbils were given $0.5 \mathrm{~mL}$ sunflower oil by gavage, always between 08.30-09.00, to avoid any possible rhythmic variations in metabolic status. 2.5 hours after per-os taking sunflower oil, the gerbils were anesthetized by inhalation diethylether and blood was collected from abdominal vein.

\section{Chylomicron preparation}

Blood samples were pooled (five animals per one samples). Whole pooled blood was collected into

Table I Composition of basal diet

\begin{tabular}{|l|c|c|c|c|c|}
\hline Ingredient & Amount $(\mathrm{g} / \mathrm{kg})$ & Ingredient & Amount $(\mathrm{mg} / \mathrm{kg})$ & Ingredient & Amount $(\mathrm{mg} / \mathrm{kg})$ \\
\hline Egg white & 197.8 & Vitamin A & 0.72 & Thiamin & 5 \\
\hline Corn starch & 535.3 & Vitamin E & 22 & $\mathrm{~B}_{12}$ & 0.010 \\
\hline Dextrinized corn starch & 91.2 & Vitamin D & 0.025 & $\mathrm{Ca}$ & 5000 \\
\hline Sunflower oil & 79.7 & Vitamin K & 1 & $\mathrm{NaCl}$ & 3600 \\
\hline Cellulose & 56.9 & Niacin & 15 & $\mathrm{P}$ & 3000 \\
\hline Vitamin, mineral mix & 39.1 & Folic acid & 0.5 & $\mathrm{Mg}$ & 1500 \\
\hline \multirow{5}{*}{} & & Ca pantothenat & 16 & $\mathrm{Fe}$ & 35 \\
\cline { 3 - 6 } & Riboflavin & 3 & $\mathrm{Mn}$ & 10 \\
\cline { 3 - 6 } & & Biotin & 0.2 & $\mathrm{Cu}$ & 5 \\
\cline { 3 - 6 } & & Pyridoxine & 8 & $\mathrm{Se}$ & \\
\hline
\end{tabular}


EDTA tubes and plasma was harvested by centrifugation at $1500 \times \mathrm{g}$ for $15 \mathrm{~min}$ immediately after collection. Chylomicrons were isolated by sequential flotation ultracentrifugation, following the method of Borel (22). Chylomicrons were stored at $-80{ }^{\circ} \mathrm{C}$ until analyzed.

\section{Chylomicron analysis procedure}

One $\mathrm{mL}$ of chylomicron phase was introduced into the appropriate flask, $1.2 \mathrm{~mL}$ of absolute ethanol containing $0.05 \%$ BHT (w/v) was added and warmed up for 2 minutes. After addition of $0.4 \mathrm{~mL}$ of $60 \% \mathrm{KOH}$ $(\mathrm{w} / \mathrm{v})$ to the mixture, samples were vortexed for $1 \mathrm{minu}-$ te. Reflux condenser was fit the to the flask and boiled for 1 hour. One $\mathrm{mL}$ of water and $3 \mathrm{~mL}$ of hexane were added to the samples, and vortexed. The upper layer was removed (hexane), and procedure was repeated with addition of $2 \mathrm{~mL}$ of hexane. Five $\mathrm{ml}$ of $20 \% \mathrm{HCl}$ (w/w) was added into water residue layer and extracted three times with 8,3 and $2 \mathrm{~mL}$ of diethylether. Three diethylethar extracts were combined and washed three times with $6 \mathrm{~mL}$ of water, until free for acid, using the methyl red solution as indicator. Diethylethar extracts were transferred into conical flask and evaporated to dryness by vacuum evaporator (23). Due to chylomicron composition, we used the amount of dried total fatty acids to representing the mass of chylomicrons.

\section{Determination of chylomicron fatty acids compositions by GL-chromatography}

Dried samples were methylated by the addition of $1 \mathrm{~mL}$ of the methanolic boron trifluoride solution into obtained dry residue. Reflux condenser was fit to the conical flask and warmed up exactly 3 minutes, and cooled to room temperature. Then, the condenser was removed. Liquids in samples were transferred into tube, $1 \mathrm{~mL}$ of water was added and extracted three times with 2, 1 and $1 \mathrm{~mL}$ hexane. Three hexane extracts were combined and transferred into second conical flask and evaporated by vacuum evaporator to approximately $0.5 \mathrm{~mL}$. This solution containing methyl esters of fatty acid may be injected directly into the column for gas-liquid chromatography (24). Fatty acids composition was analyzed using Varian 1400 fitted with a hydrogen flame ionization detector. Metalic column $(3 \mathrm{~m} \times 3.2 \mathrm{~mm})$ packed with $20 \%$ LAC-3R728 on Chromosorb W/AW, 80 mesh was used. The column detector and injector port were maintained at 180, 235 and $235^{\circ} \mathrm{C}$, respectively. Nitrogen was used as carrier gas (24 mL/min).

\section{Statistical analysis}

Data are expressed as the mean \pm SD and statistical significance and other statistical tests were established by protocols described in Hinkle et al (25).

\section{Results}

\section{Chylomicron concentration}

Chylomicrons consisted mostly of triacylglicerol (87\%) and small amounts of free cholesterol (2.1\%), esterified cholesterol (3.9\%), and phospholipids (PL) (4.3\%) (13) and that is the reason why the mass of fatty acids after saponification can be used to represent the mass of chylomicrons. Obtained values of chylomicron concentrations in plasma in LZ- and SZ- groups treated with oral dose of sunflower oil show that SZ-group had significantly $(p<0.001)$ higher amount of chylomicrons in plasma $(5.42 \pm 0.28)$ than LZ-group (3.96 \pm 0.24$)$.

\section{Fatty acids composition of chylomicrons}

In chylomicrons, following fatty acids were found: 16:0, 16:1, 17:0, 17:1, 18:0, 18:1, 18:2, 18:3, 20:0, $21: 0$ and $20: 4$. The concentrations of fatty acids in chylomicron, in LZ- and SZ- groups are shown in Table II. Dominant fatty acids identified in chylomicrons, in both groups were: 18:2, 18:1, 16:0, and 18:0, which represent 49.6, 26.9, 13.3 and $5.9 \%$ of chylomicron mass in LZ-group and 41.4, 30.2, 15.3 and 7.0\%, in SZ group, respectively. The percentage of dominant fatty acids in chylomicrons in both groups was similar, to the percentage of the same fatty acids in sunflower oil (26), due to their dietary origin. The concentration of other fatty acids in chylomicrons, which were not dietary origin: 16:1, 17:0, 17:1, 18:3, 20:0 in both groups was similar, except for arachidonic acid (20:4). The results show that LZ-group had significantly ( $p<0.01)$ higher concentration of $20: 4$ in chylomicrons $(4.2 \pm 1)$ than SZ-group $(0.8 \pm 0.4)$, (Table II).

Table II Concentration of fatty acids in chylomicron, in LZ- and SZ- groups treated with oral dose of sunflower oil $(n=5)$ N.S. non significant

\begin{tabular}{|c|c|c|c|}
\hline Fatty acids & $\begin{array}{c}\text { Low Zn group } \\
(\mu \mathrm{g} / \mathrm{mg})\end{array}$ & $\begin{array}{c}\text { Suppl Zn } \\
\text { group }(\mu \mathrm{g} / \mathrm{mg})\end{array}$ & Significance \\
\hline $16: 0$ & $133 \pm 5$ & $153 \pm 12$ & N.S. \\
\hline $16: 1$ & $16.4 \pm 4.4$ & $18.4 \pm 4.3$ & N.S. \\
\hline $17: 0$ & $5.6 \pm 2.4$ & $18.9 \pm 9.5$ & N.S. \\
\hline $17: 1$ & $8.2 \pm 3.3$ & $14.2 \pm 4.9$ & N.S. \\
\hline $18: 0$ & $59 \pm 5$ & $70 \pm 9$ & N.S. \\
\hline $18: 1$ & $269 \pm 6$ & $302 \pm 21$ & N.S. \\
\hline $18: 2$ & $496 \pm 16$ & $414 \pm 58$ & N.S. \\
\hline $20: 0$ & $3.5 \pm 0.7$ & $3.7 \pm 0.6$ & N.S. \\
\hline $18: 3$ & $3.7 \pm 0.7$ & $3.6 \pm 0.3$ & N.S. \\
\hline $21: 0$ & $1.7 \pm 0.4$ & $2.1 \pm 0.4$ & N.S. \\
\hline $20: 4$ & $4.2 \pm 1$ & $0.8 \pm 0.4$ & $* *$ p $<0.01$ \\
\hline
\end{tabular}




\section{Discussion}

The present study confirmed that absorption of dietary fat is significantly lowered impared in gerbils fed with a low zinc diet. The data provide clear evidence that SZ-group had significantly higher amount of chylomicrons in plasma than LZ-group. Some earlier studies have shown that enterocyte of Zn-deficient animals accumulates lipid droplets in the enterocyte and fails to transport the lipids via chylomicrons. The tendency to accumulate lipid droplets appears to be due to a lack of surface components such as phospholipid, which are required for chylomicron synthesis (15).

The surface coat of chylomicron contains apolipoproteins apo B-48, apo C-II, apo C-III, apo E, apo A-I and apo A-IV (12). Study on animals showed that zinc deficiency produced an increase in apo A-I (16) and decrease in apo B-48 (17). Changes in chylomicron apoproteins produced by zinc deficiency are due in part to postsyntetic modification of intestinal chylomicrons (16). Defect in luminal PC hydrolysis is the primary cause of the impaired absorption of fat observed in zinc deficiency (15). The most of the PC of biliary or dietary origin is hydrolized by pancretic phospholipase $\mathrm{A}_{2} \quad\left(\mathrm{PLA}_{2}\right)$ to lysophosphatidylcholine (lysoPC) (27). According to Koo $(7,28)$, the luminal availability of lysoPC, rather than intact PC, could be limited in LZ group, resulting in impaired absorptions of fat and fat soluble vitamins. PC and lysoPC can be taken up directly by the brush-border membrane of the enterocyte (29). LysoPC, once taken up by the enterocytes, is reacylated to $P C$, which is utilized for formation of the PC coat of chylomicrons (14).

Pancreatic PLA 2 hydrolitically removes the Sn-2 fatty acyl moiety from phospholipids. Although the enzyme is known to require $\mathrm{Ca}^{++}$for its activity (30), evidence also indicates that the enzyme binds zinc avidly in vitro and its activity is stimulated marcedly by zinc in the presence of $\mathrm{Ca}^{++}$and bile salts (31). Noh and Koo (15) reported that luminal hydrolysis of phosphatidylcholine by pancreatic $\mathrm{PLA}_{2}$ in rats fed with lower amount of zinc was impaired and the absorption of fats decreased.

Our data noted no significant differences in distribution of fatty acids in chylomicrons in LZ- and SZgroups, except for arachidonic acid (20:4), where lower amount in SZ group was measured.

Fatty acids profile of diet is reflected in the fatty acid profile of the chylomicron (32). Sunflower oil given to gerbils do not contain arachidonic acid (26). The origin of this fatty acids determined in chylomicrons was from phospholipids.

Phospholipids contain a large portion of polyunsaturated fatty acids (PUFAs), 18:2, 20:3, 20:4, 22:4, 22:5 (33), derived from dietary linoleic acid and alfalinoleic acid by elongation and desaturation processes. Some studies on animals showed, higher levels of n-3 PUFA and lower levels of n-6 PUFA, included arachidonic acid, in liver phosphatidilcholin from Zn-deficient rats than from $Z n$-adequate rats $(34,35)$. This was confirmed on $\mathrm{Zn}$-deficient rats fed with various types of dietary fat (34-36).

Results from other studies reported increased amount of arachidonic acid in total phospholipids (37, 38) and total lipids (39) in Zn-deficient rats. As it could be seen, the results reported in literature are contradictory. The fatty acid composition of total lipids depends on the ratio between triacylglicerols and phospholipids, thus the pool size of triglycerides influences its fatty acid composition (40).

Increased levels of arachidonic acid found in chylomicron fraction of $\mathrm{Zn}$ - deficient gerbiles might be due to decreased concentration of chylomicrons dietary triacylglicerol of Zn-deficient gerbiles.

In summary, the present study confirms earlier findings that the intestinal fat absorption is regulated by a mechanism sensitive to the zinc diet. Our observations here provide new evidence that distribution of fatty acids in chylomicrons is mainly unaffected by zinc status, except for 20:4. 


\title{
EFEKAT ISHRANE CINKOM NA DISTRIBUCIJU MASNIH KISELINA U HILOMIKRONIMA PLAZME
}

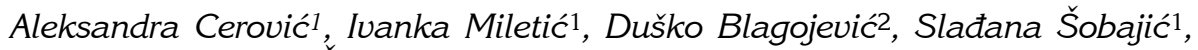 \\ Miodrag Cólić3, Milijana Vasiljeuska ${ }^{3}$, Milica Poznanić4
}

${ }^{1}$ Farmaceutski fakultet, Institut za bromatologiju, Beograd, Srbija i Crna Gora

IInstitut za biološka istraživanja "Siniša Stanković«, Odeljenje za fiziologiju, Beograd, Srbija i Crna Gora 3Vojno medicinska akademija, Institut za eksperimentalnu medicinu, Beograd, Srbija i Crna Gora ${ }^{4}$ Centar za ispitivanje namirnica, Odeljenje za instrumentalnu hemiju, Beograd, Srbija i Crna Gora

\begin{abstract}
Kratak sadržaj: Ispitivan je efekat unosa dijetarnog cinka na distribuciju masnih kiselina u hilomikronima plazme. Eksperiment je rađen na mužjacima gerbila, hranjenim standardnom dijetom, ad libitum, u toku 3 nedelje hrana je sadržala 8 ili 38 mg cinka po kg hrane (grupa sa smanjenim unosom cinka, LZ i grupa sa povećanim unosom cinka, SZ, respektivno). Dvadeset prvog dana, životinjama je dato suncokretovo ulje sondom. Nakon 2,5 časa, krv je uzimana iz abdominalne vene i uzorci su pulovani (5 životinja za jedan uzorak). Hilomikronske frakcije su izolovane ultracentrifugiranjem i merena je masa suvih hilomikrona. Masnokiselinski sastav lipida u hilomikronima je određivan gasno-tečnom hromatografijom. Nađena je značajno veća količina hilomikrona u plazmi SZ grupe nego u LZ grupi. U hilomikronima su nađene sledeće masne kiseline: 16:0, 16:1, 17:0, 17:1, 18:0, 18:1, 18:2, 18:3, 20:0, 21:0 i 20:4. Zastupljenost pojedinačnih masnih kiselina u hilomikronima obe grupe bila je slična, izuzev za 20:4 gde je izmerena niža količina u SZ grupi. Ishrana cinkom ne utiče na distribuciju većine masnih kiselina u hilomikronima. Dobijeni rezultati ukazuju da cink utiče na metabolizam masti i to u delu formiranja hilomikrona, ali je uticaj ograničen na količinu formiranih hilomikrona, ali ne i distribuciju pojedinih masnih kiselina u hilomikronima.
\end{abstract}

Ključne reči: dijeta sa smanjenim unosom Zn, dijeta sa povećanim unosom Zn, masne kiseline, hilomikroni

\section{References}

1. Prasad AS. Role of zinc in human health. Biol Assoc Med 1991; 83: 558-60.

2. Cousins R. Zinc In: Ziegler EE, Filer LJ. Present knowledge in nutrition. Washingot DC: ILSI Press, 1996; 293 306.

3. Cunnane SC. Zinc: Clinical and biochemical significance. CRS Press, Boca Raton, Fla. 1988.

4. Koo SI, Turk DE. Effects of zinc deficiency on intestinal transport of triglycerides in the rat. J Nutr 1977; 107: 909-19.

5. Koo SI, Henderson DA, Algilani C, Norvel JE. Effect of marginal zinc deficiency on the morphological characteristics of intestinal nascent chylomicrons and distribution of soluble apoproteins of lymph chylomicrons. Am J Clin Nutr 1985; 42: 671-80.

6. Koo SI, lee CC, Norvell JE. Effect of marginal zinc deficiency on the apolipoprotein-B content and size of mesenteric lymph chylomicrons in adult rats. Lipids 1987; 22: $1035-40$.

7. Ahn J, Koo SI. Intraduodenal phosphatidylcholine infusion restores the lymphatic absorption of vitamin A and oleic acid in zinc-deficient rats. Nutritional Biochemistry 1995; 6: 604-12.

8. Eder K, Mirchgessner M. Dietary zinc deficiency and fatty acid metabolism in rats. Nutritional Research 1996; 16: 1179-89.
9. Wang F, Wang X, Liu Y, Tian W-X, Zhou H-M. Inhibitive effect of zinc ion on fatty acid synthase from chicen liver. International Jurnal of Biochemistry and Biology 2003; 35: 391-400.

10. Kettler SI, Eder K, Kettler A, Kirchgessner M. Zinc deficiency and the activities of lipoprotein lipase in plasma and tissues of rats force-fed diets with coconut oil or fish oil. J Nutr Biochem 2000; 11: 132-8.

11. Groff JL, Gropper SS. Lipids. In: Groff JL, Gropper SS. Advanced nutrition and human metabolism. Canada: Wadsworth, Thomson Learning, 2000; 123-60.

12. Grundy SM. Dietary Fat. In: Ziegler EE, Filer LJ. Present knowledge in nutrition. Washington DC: ILSI Press, 1996; 44-57.

13. Hatch FT, Lees RS. Practical methods for plasma lipoprotein analysis. Adv Lipid Resear 1968; 6: 1-63.

14. Tso P, Seobey M. The role of phosphatidylcholine in the absorption and transport of dietary fat. In: Kuksis A, Ed. Fat absorption. 1986. Boca Raton FL: CRC Press. 17795.

15. Noh SK, Koo SI. Intraduodenal infusion of lysophosphatidylcholine restores the intestinal absorption of vitamin $A$ and $E$ in rats fed a low zinc diet. Exp Biol Med (Maywood) 2001; 226 (4): 342-8.

16. Koo Si, Henderson DA, Algilani K, Norvell JE. Effect of marginal zinc deficiency on the morphological characte- 
ristics of intestinal nascent chylomicrons and distribution of soluble apoproteins of 5 chylomicrons. Am J Clin Nutr 1985; 42: 671-80.

17. Koo SI, Lee CC, Norvell JE. Effect of marginal zinc deficiency on the apolipoprotein-B content and size of mesenteric lymph chylomicrons in adult rats. Lipids 1987; 22: $1035-40$.

18. Fielding BA, Callow J, Owen RM, Samra JS, Matthews DR, Frayn KN. Postprandial lipemia: The origin of an early peak studies by specific dietary fatty acid intake during sequential meals. Am J Clin Nutr 1996; 63: 36-41.

19. Groot PHE, de Boer BCJ, Haddeman E, Houtsmuller UMT, Hulsmann WC. Effect of dietary fat composition on the metabolism of triacylglycerol-rich plasma lipoproteins in the postprandial phase in meal-fed rats. J Lipid Res 1988; 29: 541-55.

20. Levy E, Roy CC, Goldstein R, Bar-On H, Ziv E. Metabolic fate on chylomicrons obtained from rats maintained on diets varying in fatty acid composition. J Am Coll Nutr. 1991; 10: 69-78.

21. Benevenga NJ, Calvert C, Eckhert CD, Fahey GC, Greger JL, et al. Nutrient Requirements of laboratory animals. In: Benevenga NJ, Calvert C, Eckhert CD, Fahey GC, Greger JL. Nutrient Requirements of the gerbil. Natl Academies Press 1995: 140-3.

22. Borel P, Mekki N, Boirie Y, Partier A, Glorier P, et al. Postprandial chylomicron and plasma vitamin $E$ responses in healthy older subjects compared with younger ones. Eur J Clin Invest 1997; 19: 476-82.

23. Službeni list SFRJ Broj 25, 3. maj 1973. strana 832.

24. Animal and vegetable fats and oils- preparation of methyl esters of fatty acids. ISO 5509-1978 (E).

25. Hinkle ED. Applied Statistics for Behavioral Sciences. Third Edition, Boston, Houghton Mifflin Company. Wiersma W \& Jurs GS (1994)

26. Službeni list SRJ. Broj 45, 20 avgust 1999. strana 5.

27. Homan R, Hamelehle KL. Phospholipase A2 relieves phosphatidylcholine inhibition of micellar cholesterol absorption and transport by human intestinal cell line Caco-2. J Lipid Res 1998; 39: 1197-209.

28. Kim E-S, Noh SK, Koo SI. Marginal zinc deficiency lowers the lymphatic absorption of alfa-tocoferol in rats. J Nutr 1998; 128: 265-70.
29. Thurnhofer $\mathrm{H}$, Hauser $\mathrm{H}$. The uptake of phosphatidylcholine by small intestinal brush border membrane is protein mediated. Biochim Biophys Acta 1990; 1024: 249-62.

30. Dennis EA. Diversity of group types, regulation and function of phospholipase A2 in the rat. J Biol Chem 1994; 269: $13057-60$

31. Lindahl M, Tagesson C. Zinc $\left(\mathrm{Zn}^{2+}\right)$ binds to and stimulates the activity group I but not group II phospholipase $A_{2}$. Inflamtion 1996; 20: 599-611.

32. Fielding BA, Callow J, Owen RM, Samra JS, Matthews DR, Frayn KN. Postprandial lipemia: The origin of an early peak studies by specific dietary fatty acid intake during sequential meals. Am J Clin Nutr 1996; 63: 36-41.

33. Eder K, Kirchgessner M. Zinc deficiency and the desaturation of linoleic acid in rats force-fed, fat free diets. Biol Trace Elem Res 1996; 54 (2): 173-83.

34. Eder $\mathrm{K}$, Kirchgessner $M$. The dietary fat influences the effect of zinc deficiency on liver lipids and fatty acids in rats force-fed equal quantities of diet. J Nutr 1994; 124 : 1917-26.

35. Eder K, Kirchgessner M. Levels of polyunsaturated fatty acids in tissues from zinc deficient rats fed a linseed oil diet. Lipids 1994; 29: 839-44.

36. Eder K, Kirchgessner M. Activities of liver microsomal fatty acids desaturases in zinc deficient rats force-fed a diets with a coconut oil/ safflower oil mixture or linseed oil. Biol Trace Elem Res 1995; 48: 215-30.

37. Fogerty AC, Ford GL, Dreosti IE, Tinsley IJ. Zinc deficiency and fatty acid composition of tissue lipids. Nutr rep Int 1988; 32: 1009-19.

38. Kudo N, Nakagawa Y, Waku K. Effects of zinc deficiency on the fatty acid composition and metabolism in rats fed a fat-free diet. Biol Trace Elem Res 1990; 24: 49-60.

39. Huang YS, Cunnane SC, Horrobin DF, Davignon J. Most biological effects of zinc diet deficiency are corrected by gamma-linoleic acid but not by linoleic acid. Atherosclerosis 1982; 41: 193-207.

40. Cunnane SC, Huang YS, Manku MS. Triacylglycerol content of arachidonic acid varies inversely with total triacylglycerol in liver and plasma. Biochim Biophys Acta 1986; 876: $183-86$

Received: April 7, 2004

Accepted: October 15, 2004 